\title{
Fast Dissolving Oral Film of Piroxicam: Solubility Enhancement by forming an Inclusion Complex with $\beta$-cyclodextrin, Formulation and Evaluation
}

\author{
Shripathy Dharmasthala ${ }^{1, *}$, Addai Ramakrishna Shabaraya', Gladson Simon Andrade', Ravi Gundadka Shriram², Srinivas Hebbar ${ }^{2}$, \\ Akhilesh Dubey ${ }^{2}$ \\ 'Department of Pharmaceutics, Srinivas College of Pharmacy, Mangaluru-574143, Karnataka, INDIA. \\ ${ }^{2}$ Department of Pharmaceutics, N.G.S.M Institute of Pharmaceutical Sciences, NITTE (Deemed to be University), Mangaluru-575018, Karnataka, INDIA.
}

\begin{abstract}
Objective: Piroxicam is a long-acting potent nonsteroidal anti-inflammatory drug (NSAID) which has a very low solubility in Gastrointestinal (GI) fluids results in poor bioavailability after oral administration. The present investigation aimed to formulate and evaluate fast dissolving oral films containing piroxicam to overcome solubility and bioavailability problems thereby to facilitate the convenience of pediatric and geriatric patients. Method: The inclusion complexes of piroxicam with $\beta$-cyclodextrin were prepared. In vitro dissolution study was performed to fix the ratio with better dissolution rate. The selected inclusion complex was then utilized for the preparation of fast dissolving oral films by solvent casting method using sodium $\mathrm{CMC}$ / chitosan as film-forming agents, sodium starch glycolate/crospovidone as super disintegrating agents. PEG 400 used as a plasticizer. Formulations (F1-F12) were prepared and evaluated for their physicochemical properties. In vitro disintegration, dissolution and permeation studies were also carried out. Results: Formulation F2 showed the minimum in vitro disintegration time $(14.94 \pm 3.06 \mathrm{~s})$, formulation F9 showed the maximum in vitro disin-
\end{abstract}

tegration time $(36.66 \pm 1.05 \mathrm{~s})$. The formulations F6 and F4 showed better drug release of $94.4 \%$ and $92.9 \%$ respectively. Better drug permeation of $96.65 \%$ was obtained from the formulation F6 in $40 \mathrm{~s}$. Conclusion: The study concluded that the fast dissolving films achieved quicker onset of action compared to the conventional preparations. The formulation found promising to obtain better therapeutic efficiency.

Key words: Fast dissolving film, Inclusion complex, $\beta$-cyclodextrin, Piroxicam. Correspondence

Mr. Shripathy D, Department of Pharmaceutics, Srinivas College of Pharmacy, Mangaluru-574143, Karnataka, INDIA.

Phone: +91 9448477359

Email: shripathy1@yahoo.com

DOI: 10.5530/jyp.2019.11.1

\section{INTRODUCTION}

The oral route of drug administration is the most frequently used and acceptable among the various drug administration routes due to its simplicity and convenience, which improve patient compliance. Peroral dosage forms can be distinguished as solid or liquid oral dosage forms. The solid dosage forms include pills, capsules, granules and powders, while the liquid dosage forms include solutions, suspensions or emulsions offering more advantages over the solid dosage forms. These liquid dosage forms also exhibit some disadvantages such as dose inaccuracy, microbiological instability and found inadequate in masking the taste. In the early $19^{\text {th }}$ century the fast dissolving tablets were designed to overcome these problems associated with the liquids dosage forms. ${ }^{1}$ Fast dissolving tablets disintegrate within $60 \mathrm{~s}$ when placed in the oral cavity without administration with the water or chewing the tablet. However, due to certain disadvantages such as solid physical form, psychological fear of swallowing, chewing, friability of wafer-like porous and low pressure moulded tablet etc. A new technology was developed as a mouth dissolving film. ${ }^{2}$

Fast dissolving oral disintegrating films (ODFs) are the most advanced form of oral solid dosage forms gives rapid absorption and instant bioavailability of drugs after quick release due to high blood flow and permeability of oral mucosa. These are thin films with an area of $2-8 \mathrm{~cm}^{2}$ and drugs can be incorporated up to a single dose of $30 \mathrm{mg}$. These ODFs contain active ingredient embedded in a matrix of film-forming polymers that disintegrate within a few seconds after oral administration in saliva, even without chewing. Larger surface area of the film promotes rapid disintegration and dissolution in the oral cavity. The oromucosally absorbed drug enters the systemic circulation without undergoing first-pass hepatic metabolism hence the bioavailability of drug can be significantly greater than the conventional tablet dosage forms. Moreover, patient compliance will be more in the patients facing difficulty in swallowing and chewing. ${ }^{3}$ Fast dissolving oral films are useful in paediatric, geriatric, bedridden patients. These are also beneficial in some of the conditions such as diarrhoea, sudden allergic attacks and also useful when the local action is desired such as local anaesthetic for toothaches, oral ulcers, cold sores or teething. ${ }^{4-6}$

Piroxicam is a nonsteroidal anti-inflammatory drug (NSAID) of the oxicam class used to relieve the symptoms of painful, inflammatory conditions like arthritis. ${ }^{7}$ Piroxicam works by preventing the production of endogenous prostaglandins which are involved in the mediation of pain, stiffness, tenderness and swelling. ${ }^{7}$ Its activity is largely attributable to a central mechanism not mediated by the opi-atergic system as it is not antagonized by naloxone. ${ }^{8-10}$ One of the major problems with this drug is it has a very low aqueous solubility $(0.023 \mathrm{mg} / \mathrm{ml})$, which results in poor bioavailability after oral administration. ${ }^{11,12}$ Hence there is a need to increase the solubility of piroxicam and also to formulate a suitable dosage form in order to increase the bioavailability. For the effective management of arthritis and osteoarthritis especially in the case of 
geriatric patients, therefore it is desirable to formulate piroxicam in the form of fast dissolving oral films for the easy and effective drug delivery. In the present work, an attempt was made to enhance the solubility of piroxicam by forming an inclusion complex with $\beta$-cyclodextrin $(\beta-C D)$ and then formulated in the form of fast dissolving films and evaluated.

\section{MATERIALS AND METHODS}

\section{Materials}

Piroxicam, $\beta$-cyclodextrin, sodium CMC, chitosan, crospovidone, sodium starch glycolate and citric acid were procured from Yarrow Chem, Mumbai, India. PEG 400 was purchased from Loba Chemie Pvt Ltd., Mumbai, India. All chemicals/reagents used were of analytical grade.

\section{Methods}

\section{Compatibility study by FTIR}

Fourier Transform Infrared (FTIR) spectra matching approach was used for the detection of possible chemical interactions between the drug and polymers. Samples included pure drug and physical mixtures of drug and polymers, were mixed with a suitable quantity of potassium bromide to form dry pellets. Pellets were then scanned from 4000 to $400 \mathrm{~cm}^{-1}$ using FTIR spectrophotometer (Jasco FTIR 4100, Japan). The FTIR spectra of physical mixtures were compared with the pure drug spectrum and peak matching was done to detect any appearance or disappearance of peaks. ${ }^{13}$

\section{Preparation of inclusion complex of piroxicam with $\beta$-cyclodextrin}

Inclusion complexes were prepared by kneading method by wetting the physical mixture of piroxicam: $\beta-C D$ in different ratios 1:0.5 (IC1), 1:1 (IC2) and 1:2 (IC3) in a mortar with methanol and water mixture (1:1). The wet mass was then kneaded thoroughly with a pestle to obtain a paste-like consistency. The mass was then dried at room temperature and the dry sample was passed through sieve $\# 80$ and stored in a desiccator until further use. ${ }^{14}$

\section{Evaluation of Inclusion Complex Drug content and in vitro drug release}

Inclusion complex $(25 \mathrm{mg})$ was taken in a $50 \mathrm{ml}$ volumetric flask and dissolved in methanol and diluted suitably with phosphate buffer of $\mathrm{pH}$ 6.8. Then the solution was filtered through a Whatman filter paper and analysed using a UV spectrophotometer (Shimadzu UV-1201, Japan) at $350 \mathrm{~nm}$. The in vitro drug release study was carried out using USP dissolution testing apparatus type-II (EDT-08Lx, Electrolab, Mumbai, India). Inclusion complex ( 100 mg of piroxicam) was taken in $900 \mathrm{ml}$ of the dissolution medium (Phosphate buffer of $\mathrm{pH}$ 6.8). The temperature was maintained at $37 \pm 0.5^{\circ} \mathrm{C}$ and the paddle speed was set at $50 \mathrm{rpm}$. The sample $(5 \mathrm{ml})$ was withdrawn at specific time intervals and an equal volume of fresh medium was replaced to maintain the sink condition. The sample withdrawn was filtered and diluted with phosphate buffer $\mathrm{pH} 6.8$ suitably before the analysis and absorbance was measured using a UV spectrophotometer at $350 \mathrm{~nm} .^{15}$

\section{Formulation of Fast Dissolving Film of Piroxicam}

The fast dissolving films of piroxicam were prepared by solvent casting technique using film forming polymer sodium CMC or chitosan. The calculated amount of polymer was added in a $3 / 4^{\text {th }}$ volume of water with continuous stirring and the inclusion complex containing piroxicam was incorporated in the polymeric solution. Sodium starch glycolate or crospovidone was then added to the polymeric solution and stirred vigorously. Then citric acid and PEG 400 were added and the final volume was adjusted up to $15 \mathrm{ml}$ with distilled water. The resulting bubble-free viscous solution was cast on a petri dish (area of $69.362 \mathrm{~cm}^{2}$ ) then kept in a hot air oven at $40^{\circ} \mathrm{C}$ for $24 \mathrm{~h}$. The composition of piroxicam oral films are given in Table 1. The films were cut into the size of $2 \times 2 \mathrm{~cm}$ containing $10 \mathrm{mg}$ of piroxicam were wrapped in an aluminium foil and stored in a desiccator until further use. ${ }^{16,17}$

\section{Evaluation of Piroxicam Fast Dissolving Film}

The thickness of the fast dissolving film $(2 \times 2 \mathrm{~cm})$ was determined by using a screw gauge (Kayco India Ltd., Delhi, India). The thickness of each film at three different places was determined and calculated in triplicate. To determine content uniformity, fast dissolving film of size $(2 \times 2 \mathrm{~cm})$ was cut into small pieces and transferred into a graduated glass-stoppered flask containing about $100 \mathrm{ml}$ of phosphate buffer of 6.8 $\mathrm{pH}$. The flask was shaken for $4 \mathrm{~h}$ in a mechanical shaker. The solution was filtered and the amount of drug present was determined by measuring the absorbance using UV spectrophotometer at $350 \mathrm{~nm}$ after suitable dilutions with phosphate buffer of $\mathrm{pH}$ 6.8. Weight variation was calculated after determining the individual and average weights of the films of size $(2 \times 2 \mathrm{~cm})$ using an electronic analytical balance (Essae Teraoka, Japan), performed in triplicates. To determine the surface $\mathrm{pH}$ oral film was placed in a petri dish and moistened with $0.5 \mathrm{ml}$ of distilled water and kept for $30 \mathrm{~s}$. The $\mathrm{pH}$ was measured by bringing the electrode of the $\mathrm{pH}$ meter (Systronics, Mumbai, India) in contact with the surface of the oral film. The procedure was performed in triplicate. The tensile strength apparatus (F.4026, Instron Ltd., Japan) had upper fixed and the lower movable clamps. The film sample $(6 \times 2 \mathrm{~cm})$ was clamped between the two clamps and the force at tearing and elongation were noted. Two mechanical properties, namely, tensile strength and percentage elongation were computed for the evaluation of the film. Folding endurance was determined by taking the film size of $(4 \times 2 \mathrm{~cm})$ and repeatedly folding at the same place till visible cracks appear. The film of $4 \mathrm{~cm}^{2}$ area was cut out and weighed accurately and kept in a desiccator containing fused anhydrous calcium chloride. After $24 \mathrm{~h}$ the film was removed and weighed again and $\%$ moisture content was calculated. ${ }^{18}$

\section{In vitro Disintegration}

The film size $(2 \times 2 \mathrm{~cm})$ required for dose delivery was placed into one tube of disintegration apparatus IP (ED-2L, Electrolab, Mumbai, India) and a disc was placed at the surface of the tube. The assembly was suspended in a beaker containing phosphate buffer of $\mathrm{pH} 6.8$ and the apparatus was operated until the film disintegrated. The time required for breakdown of the film was noted as in vitro disintegration time. ${ }^{19}$

\section{In vitro Drug Release}

The dissolution studies were carried out using USP XXIII type-I dissolution apparatus (EDT-08Lx, Electrolab, Mumbai, India) at $37 \pm 0.5^{\circ} \mathrm{C}$ and $50 \mathrm{rpm}$ using phosphate buffer of $\mathrm{pH} 6.8(300 \mathrm{ml})$ medium. Each film with dimension $(2 \times 2 \mathrm{~cm})$ placed on a basket was submerged into dissolution medium and stirred. Samples were withdrawn at 0, 20, $30,40,60,80,100,120$ and $140 \mathrm{~s}$ time intervals and the same amount of the fresh medium was replaced. The samples withdrawn were filtered through $0.45 \mu \mathrm{m}$ Whatman filter paper and were analysed using a UV spectrophotometer at $350 \mathrm{~nm} .{ }^{20}$

\section{In vitro Permeation}

In vitro permeation through cellophane membrane was studied using the Franz diffusion cell of the internal diameter of $2.5 \mathrm{~cm}$. The cellophane membrane was mounted between the donor and receptor compartments. The receptor compartment was filled with $100 \mathrm{ml}$ of phosphate buffer of $\mathrm{pH} 6.8$ which was maintained at $37 \pm 0.5^{\circ} \mathrm{C}$. One film of dimension $(2 \times 2 \mathrm{~cm})$ which was previously moistened with few drops of phosphate buffer of $\mathrm{pH} 6.8$ was placed in the donor compartment. The donor 
compartment was filled with $5 \mathrm{ml}$ of phosphate buffer of $\mathrm{pH}$ 6.8. From the receptor compartment, $1 \mathrm{ml}$ sample was withdrawn at definite time intervals and the same amount of fresh medium was replaced each time. The percentage of piroxicam permeated was determined by measuring the absorbance using UV spectrophotometer at $350 \mathrm{~nm}^{.1}$

\section{RESULTS}

\section{Compatibility Study by FTIR}

The FTIR spectra of pure drug were characterized by two $\mathrm{C}=\mathrm{O}$ stretches at $1586.16 \mathrm{~cm}^{-1}$ and $1726.94 \mathrm{~cm}^{-1}$ respectively indicated the presence of two $-\mathrm{O}$ atoms, $\mathrm{S}=\mathrm{O}$ stretching at $3640.95 \mathrm{~cm}^{-1}, \mathrm{C}=\mathrm{C}$ stretching at $1586.16 \mathrm{~cm}^{-1}$. All the characteristic IR peaks related to pure drug piroxicam also appeared in the FTIR spectra of mixtures of drug with polymers. Overlay of FTIR spectra is shown in Figure 1.

\section{Evaluation of Inclusion Complex of Piroxicam with $\beta$-Cyclodextrin}

The percentage drug content of prepared complexes was found to be $91.73 \pm 0.56 \%$ (IC1), $91.67 \pm 0.63 \%$ (IC2) and $90.32 \pm 0.83 \%$ (IC3). In vitro dissolution study data of the pure drug piroxicam and inclusion complexes are shown in Figure 2. The complete dissolution of complexes occurred within $200 \mathrm{~s}$ in case of IC2 (1:1) and IC3 (1:2) complexes, whereas IC1 (1:0.5) complex showed only a release of $64.83 \%$ at the end of $200 \mathrm{~s}$. Complex IC2 containing 1:1 ratio of drug and $\beta$-CD showed faster dissolution rate, about $98.71 \%$ of the drug was released within $180 \mathrm{~s}$.

\section{Evaluation of Fast Dissolving Film of Piroxicam}

12 formulations were prepared using sodium CMC or chitosan (Table 1) as a polymer. The thickness of the fast dissolving films F1 to F12 varied from $0.29 \pm 0.04 \mathrm{~mm}$ to $0.46 \pm 0.09 \mathrm{~mm}$ with low standard deviation values. Formulation F1 showed the lowest thickness of $0.29 \pm 0.04 \mathrm{~mm}$ and formulation F9 showed the highest thickness of $0.46 \pm 0.09 \mathrm{~mm}$. The content uniformity for all the formulations was found to be in the range of $84.3 \pm 0.41 \%$ to $96.05 \pm 1.34 \%$. The average weight of the films was found to be in the range of $97.33 \pm 1.69 \mathrm{mg}$ to $146.66 \pm 2.05 \mathrm{mg}$. Formulation F1 showed the lowest weight of $97.33 \pm 1.69 \mathrm{mg}$ and formulation F9 showed the highest weight of $146.66 \pm 2.05 \mathrm{mg}$. The surface $\mathrm{pH}$ of the films F1 to F12 was ranging from $6.61 \pm 0.01$ to $6.88 \pm 0.04$. Film thickness, content uniformity, weight variation and surface $\mathrm{pH}$ study results of all the formulations are depicted in Table 2. The tensile strength of the films $F 1$ to $F 12$ was found to be in the range of $4.1 \pm 0.02 \mathrm{~N} / \mathrm{cm}^{2}$ to $5.6 \pm 0.07 \mathrm{~N} / \mathrm{cm}^{2}$. Formulation F1 showed the minimum tensile strength of $4.1 \pm 0.02 \mathrm{~N} / \mathrm{cm}^{2}$ whereas formulation F12 showed the maximum tensile strength of $5.6 \pm 0.07 \mathrm{~N} / \mathrm{cm}^{2}$. The percentage elongation of films F1 to $\mathrm{F} 12$ ranged between $8.81 \pm 1.17 \%$ to $31.33 \pm 2.18 \%$. Formulation F2 showed the lowest percent elongation of $8.81 \pm 1.17 \%$ and formulation F9 and F5 showed the highest percent elongation of $31.33 \pm 2.18 \%$ and $30.50 \pm 2.24 \%$ respectively. Folding endurance of the films F1 to F12 ranged from $200 \pm 1.69$ to $212 \pm 3.17$. Formulation F1 showed lower folding endurance of $200 \pm 1.69$ whereas formulation F12 showed higher folding endurance of $212 \pm 3.17$. The $\%$ moisture content of the films F1 to F12 ranged from $1.26 \pm 043 \%$ to $2.49 \pm 0.35 \%$. F5 and F9 formulation showed high \% moisture content while F2 and F4 showed low \% moisture content. Tensile strength, percentage elongation, folding endurance and $\%$ moisture content study result data is shown in Table 3.

\section{In vitro Disintegration}

All films were disintegrated rapidly. The disintegration time of the films F1 to F12 was found to be in the range between $14.94 \pm 3.06 \mathrm{~s}$ to $36.66 \pm 1.05 \mathrm{~s}$. Formulation F2 showed the minimum in vitro disintegration time, i.e., $14.94 \pm 3.06 \mathrm{~s}$ and formulation F9 showed the maximum in vitro disintegration time, i.e., $36.66 \pm 1.05 \mathrm{~s}$.

\section{In vitro Drug Release}

Results of in vitro drug release studies are depicted in Figure 3 and 4. Rapid drug dissolution was observed in case of F6 containing $6 \% \mathrm{w} / \mathrm{v}$ of crospovidone which released $94.4 \%$ followed by F4 containing $2 \% \mathrm{w} / \mathrm{v}$ of crospovidone which released $92.90 \%$, at the end of 100 s. Slow drug dissolution was observed in F5 containing $4 \% \mathrm{w} / \mathrm{v}$ of crospovidone which released $92.71 \%$ at the end of $120 \mathrm{~s}$ and F9 containing $6 \% \mathrm{w} / \mathrm{v}$ of sodium starch glycolate which released $96.51 \%$ at the end of $140 \mathrm{~s}$. It was observed that $\mathrm{T}_{90 \%}$ of the films F1 to F12 varied from $90.28 \mathrm{~s}$ to $120.83 \mathrm{~s}$. Formulation F6 showed minimum $\mathrm{T}_{90 \%}$ of $90.28 \mathrm{~s}$ and maximum $\mathrm{T}_{90 \%}$ of $120.83 \mathrm{~s}$ was observed in formulation F9 (Table 4).

Table 1: Composition of piroxicam oral films.

\begin{tabular}{|c|c|c|c|c|c|c|c|c|}
\hline \multirow[b]{2}{*}{$\begin{array}{l}\text { Formulation } \\
\text { code }\end{array}$} & \multicolumn{8}{|c|}{ Ingredients } \\
\hline & $\begin{array}{l}\text { Inclusion Complex } \\
\text { equivalent to } 173 \mathrm{mg} \text { of } \\
\text { drug }(\mathrm{mg})\end{array}$ & $\begin{array}{l}\text { Sodium CMC } \\
\qquad(\mathrm{mg})\end{array}$ & $\begin{array}{c}\text { Chitosan } \\
\text { (mg) }\end{array}$ & $\begin{array}{l}\text { Sodium starch } \\
\text { glycolate }(\mathrm{mg})\end{array}$ & $\begin{array}{c}\text { Crospovidone } \\
\text { (mg) }\end{array}$ & $\begin{array}{c}\text { Citric } \\
\text { Acid (mg) }\end{array}$ & $\begin{array}{l}\text { PEG } 400 \\
(\mathrm{ml})\end{array}$ & $\begin{array}{l}\text { Distilled water } \\
\text { upto }(\mathrm{ml})\end{array}$ \\
\hline $\mathrm{F} 1$ & 364 & 1250 & & 50 & & 100 & 0.2 & 15 \\
\hline $\mathrm{F} 2$ & 364 & 1250 & & 100 & & 100 & 0.2 & 15 \\
\hline F3 & 364 & 1250 & & 150 & & 100 & 0.2 & 15 \\
\hline $\mathrm{F} 4$ & 364 & 1250 & & & 50 & 100 & 0.2 & 15 \\
\hline F5 & 364 & 1250 & & & 100 & 100 & 0.2 & 15 \\
\hline F6 & 364 & 1250 & & & 150 & 100 & 0.2 & 15 \\
\hline F7 & 364 & & 1250 & 50 & & 100 & 0.2 & 15 \\
\hline F8 & 364 & & 1250 & 100 & & 100 & 0.2 & 15 \\
\hline F9 & 364 & & 1250 & 150 & & 100 & 0.2 & 15 \\
\hline F10 & 364 & & 1250 & & 50 & 100 & 0.2 & 15 \\
\hline F11 & 364 & & 1250 & & 100 & 100 & 0.2 & 15 \\
\hline F12 & 364 & & 1250 & & 150 & 100 & 0.2 & 15 \\
\hline
\end{tabular}


Table 2: Film thickness, drug content, average weight and surface $\mathrm{pH}$ of fast dissolving films containing piroxicam.

\begin{tabular}{ccccc}
\hline $\begin{array}{c}\text { Formulation } \\
\text { code }\end{array}$ & $\begin{array}{c}\text { Film } \\
\text { Thickness } \\
(\mathrm{mm})\end{array}$ & $\begin{array}{c}\text { Drug } \\
\text { Content } \\
(\%)\end{array}$ & $\begin{array}{c}\text { Average } \\
\text { Weight } \\
(\mathrm{mg})\end{array}$ & Surface pH \\
\hline F1 & $0.29 \pm 0.04$ & $88.45 \pm 0.96$ & $97.33 \pm 1.69$ & $6.61 \pm 0.01$ \\
F2 & $0.32 \pm 0.069$ & $96.05 \pm 1.34$ & $112.00 \pm 3.09$ & $6.65 \pm 0.03$ \\
F3 & $0.31 \pm 0.08$ & $88.1 \pm 1.38$ & $134.66 \pm 3.29$ & $6.78 \pm 0.08$ \\
F4 & $0.43 \pm 0.12$ & $94.5 \pm 0.92$ & $98.33 \pm 1.24$ & $6.79 \pm 0.05$ \\
F5 & $0.40 \pm 0.04$ & $84.3 \pm 0.41$ & $113.33 \pm 1.69$ & $6.81 \pm 0.05$ \\
F6 & $0.36 \pm 0.08$ & $88.7 \pm 1.93$ & $130.66 \pm 2.49$ & $6.72 \pm 0.03$ \\
F7 & $0.44 \pm 0.12$ & $93.3 \pm 1.88$ & $101.66 \pm 2.86$ & $6.88 \pm 0.04$ \\
F8 & $0.37 \pm 0.08$ & $92.5 \pm 2.12$ & $115.66 \pm 1.69$ & $6.83 \pm 0.06$ \\
F9 & $0.46 \pm 0.09$ & $86.5 \pm 0.96$ & $146.66 \pm 2.05$ & $6.64 \pm 0.05$ \\
F10 & $0.43 \pm 0.12$ & $87.3 \pm 0.41$ & $102.54 \pm 1.86$ & $6.66 \pm 0.08$ \\
F11 & $0.39 \pm 0.08$ & $86.2 \pm 0.92$ & $109.86 \pm 1.22$ & $6.69 \pm 0.03$ \\
F12 & $0.36 \pm 0.04$ & $91.01 \pm 1.37$ & $138.67 \pm 2.81$ & $6.67 \pm 0.09$ \\
\hline
\end{tabular}

Values are mean $\pm \operatorname{SEM}(\mathrm{n}=3)$

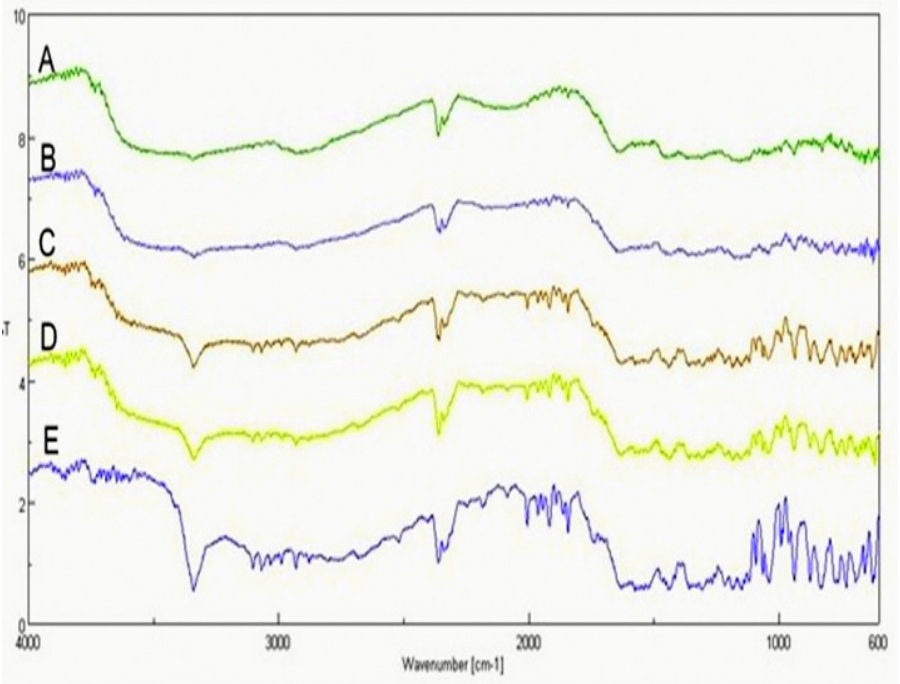

Figure 1: Overlay FTIR Spectra; Piroxicam (A), piroxicam+ betacyclodextrin (B), piroxicam + betacyclodextrin + sodium CMC (C), piroxicam+ betacyclodextrin+ chitosan (D) and piroxicam + betacyclodextrin+ chitosan+s odium CMC (E).

\section{In vitro Permeation}

In in vitro drug permeation study, the formulation F6 containing $6 \% \mathrm{w} / \mathrm{v}$ of crospovidone showed better drug permeation of $96.65 \%$ in $40 \mathrm{~s}$, formulation F4 containing $2 \% \mathrm{w} / \mathrm{v}$ crospovidone showed drug permeation of $99.13 \%$ in $45 \mathrm{~s}$, formulation F2 containing $4 \% \mathrm{w} / \mathrm{w}$ of sodium starch glycolate and formulation F7 containing $2 \% \mathrm{w} / \mathrm{w}$ of sodium starch glycolate showed drug permeation of $98.08 \%$ and $97.39 \%$ respectively at the end of $45 \mathrm{~s}$. The results obtained from the in vitro permeation studies are depicted in Figure 5 and 6.

\section{DISCUSSION}

The IR peaks obtained in the spectra of each physical mixture correlated with the peaks of the drug spectrum. Hence, it was concluded that all the polymers used were compatible with the drug and did not lead to a stability problem when used in the formulation. Piroxicam inclusion complexes with $\beta$-CD were prepared by kneading method to enhance the
Table 3: Tensile strength, percentage elongation, folding endurance and $\%$ moisture content of fast dissolving films containing piroxicam.

\begin{tabular}{ccccc}
\hline $\begin{array}{c}\text { Formulation } \\
\text { code }\end{array}$ & $\begin{array}{c}\text { Tensile } \\
\text { Strength } \\
\text { (N/cm })\end{array}$ & $\begin{array}{c}\text { Percentage } \\
\text { elongation } \\
(\%)\end{array}$ & $\begin{array}{c}\text { Folding } \\
\text { endurance }\end{array}$ & $\begin{array}{c}\% \text { moisture } \\
\text { content } \\
(\%)\end{array}$ \\
\hline F1 & $4.5 \pm 0.01$ & $9.75 \pm 2.07$ & $200 \pm 1.69$ & $1.61 \pm 0.54$ \\
F2 & $5.4 \pm 0.02$ & $8.81 \pm 1.17$ & $205 \pm 2.05$ & $1.36 \pm 0.58$ \\
F3 & $4.8 \pm 0.03$ & $18.83 \pm 2.29$ & $207 \pm 3.09$ & $1.87 \pm 0.47$ \\
F4 & $4.7 \pm 0.09$ & $22.75 \pm 2.07$ & $209 \pm 2.82$ & $1.26 \pm 0.43$ \\
F5 & $5.2 \pm 0.04$ & $30.50 \pm 2.24$ & $204 \pm 1.24$ & $2.32 \pm 0.37$ \\
F6 & $5.5 \pm 0.02$ & $12.83 \pm 1.35$ & $208 \pm 0.94$ & $1.49 \pm 0.49$ \\
F7 & $5.2 \pm 0.21$ & $15.75 \pm 1.96$ & $205 \pm 2.86$ & $1.67 \pm 0.81$ \\
F8 & $4.8 \pm 0.04$ & $27.91 \pm 2.45$ & $211 \pm 0.47$ & $1.96 \pm 0.41$ \\
F9 & $4.5 \pm 0.03$ & $31.33 \pm 2.18$ & $212 \pm 1.24$ & $2.49 \pm 0.35$ \\
F10 & $5.1 \pm 0.05$ & $21.37 \pm 1.18$ & $206 \pm 1.57$ & $1.41 \pm 0.38$ \\
F11 & $5.6 \pm 0.07$ & $26.23 \pm 2.26$ & $208 \pm 2.28$ & $2.19 \pm 0.46$ \\
F12 & $4.5 \pm 0.01$ & $28.03 \pm 2.08$ & $212 \pm 3.17$ & $1.49 \pm 0.52$ \\
\hline
\end{tabular}

Values are mean $\pm \operatorname{SEM}(\mathrm{n}=3)$

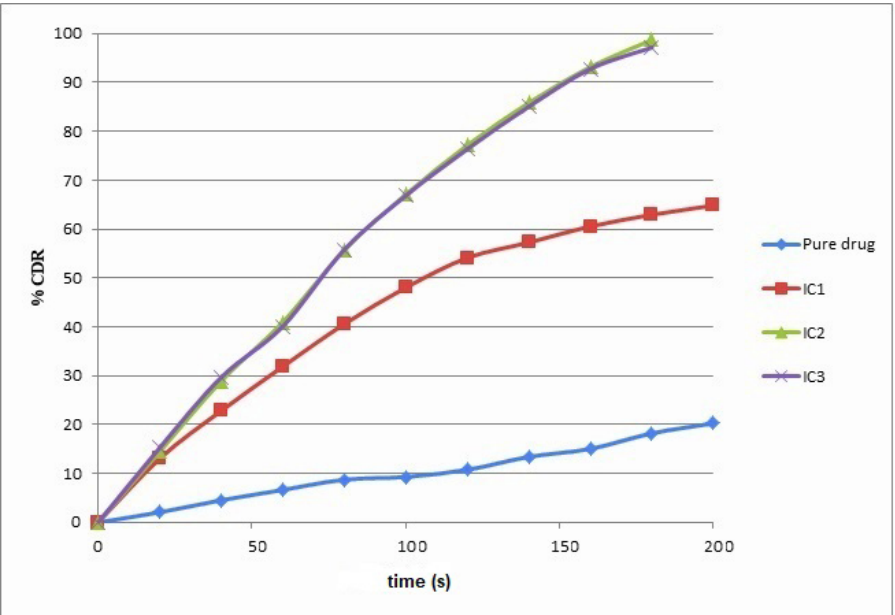

Figure 2: In vitro release pattern of piroxicam and its inclusion complexes with $\beta-C D$.

Table 4: In vitro disintegration time and $\mathrm{T}_{90 \%}$ of fast dissolving films containing piroxicam.

\begin{tabular}{ccc}
\hline $\begin{array}{c}\text { Formulation } \\
\text { code }\end{array}$ & $\begin{array}{c}\text { In vitro disintegration time } \\
\text { (s) }\end{array}$ & $\begin{array}{c}\mathbf{T}_{\mathbf{9 0}} \\
\text { (s) }\end{array}$ \\
\hline F1 & $17.40 \pm 1.62$ & $100.8 \pm 0.59$ \\
F2 & $14.94 \pm 3.06$ & $100 \pm 0.46$ \\
F3 & $25.23 \pm 2.02$ & $100.33 \pm 0.76$ \\
F4 & $28.12 \pm 1.49$ & $90.61 \pm 0.91$ \\
F5 & $34.55 \pm 0.57$ & $110.35 \pm 0.84$ \\
F6 & $20.75 \pm 1.28$ & $90.28 \pm 0.71$ \\
F7 & $22.36 \pm 1.18$ & $100.21 \pm 0.43$ \\
F8 & $31.11 \pm 2.01$ & $110.14 \pm 0.62$ \\
F9 & $36.66 \pm 1.05$ & $120.83 \pm 0.79$ \\
F10 & $26.80 \pm 1.82$ & $90.91 \pm 0.83$ \\
F11 & $22.51 \pm 2.09$ & $100.25 \pm 0.94$ \\
F12 & $27.60 \pm 3.05$ & $110.07 \pm 0.57$ \\
\hline
\end{tabular}

Values are mean $\pm \operatorname{SEM}(n=3)$ 


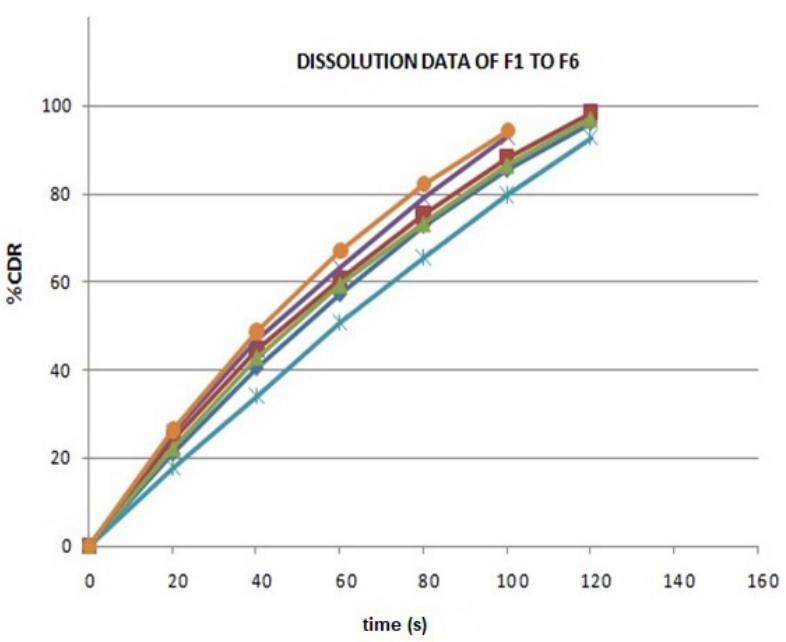

Figure 3: In vitro dissolution of F1 to F6 formulations.

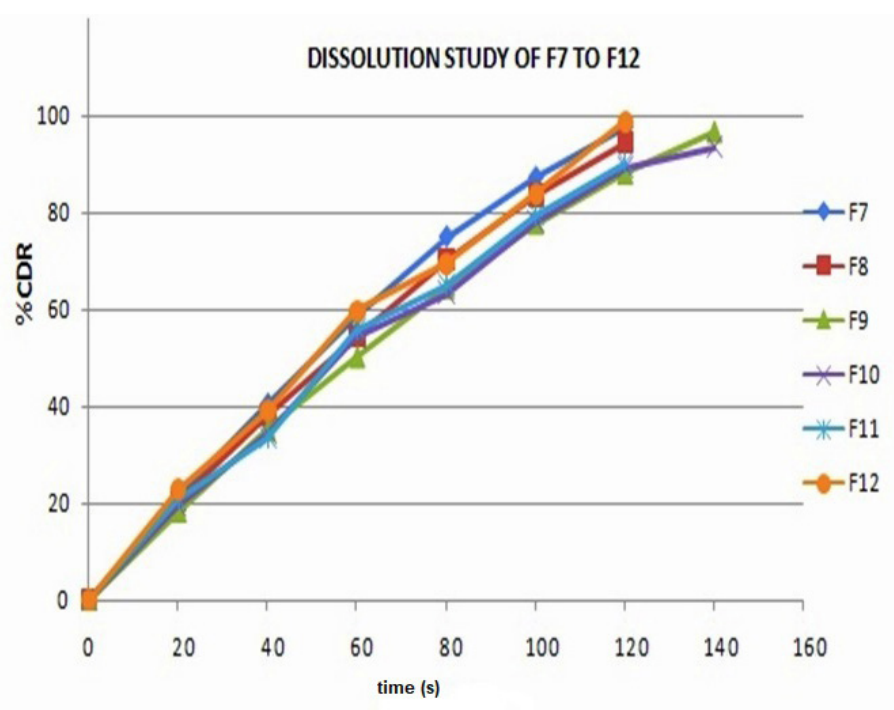

Figure 4: In vitro dissolution of F7 to F12 formulations.

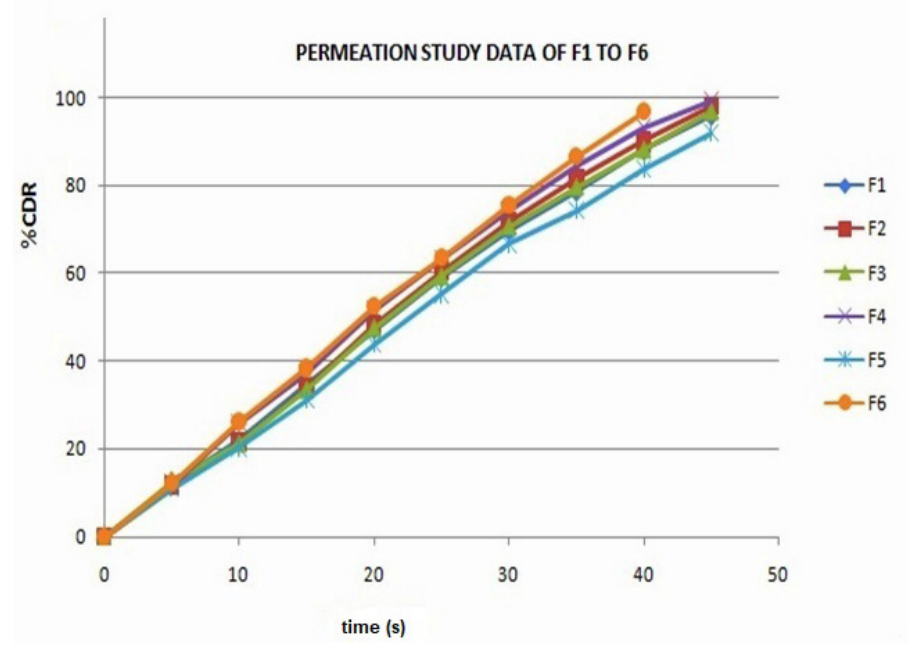

Figure 5: In vitro permeation pattern of F1 to F6 formulations.

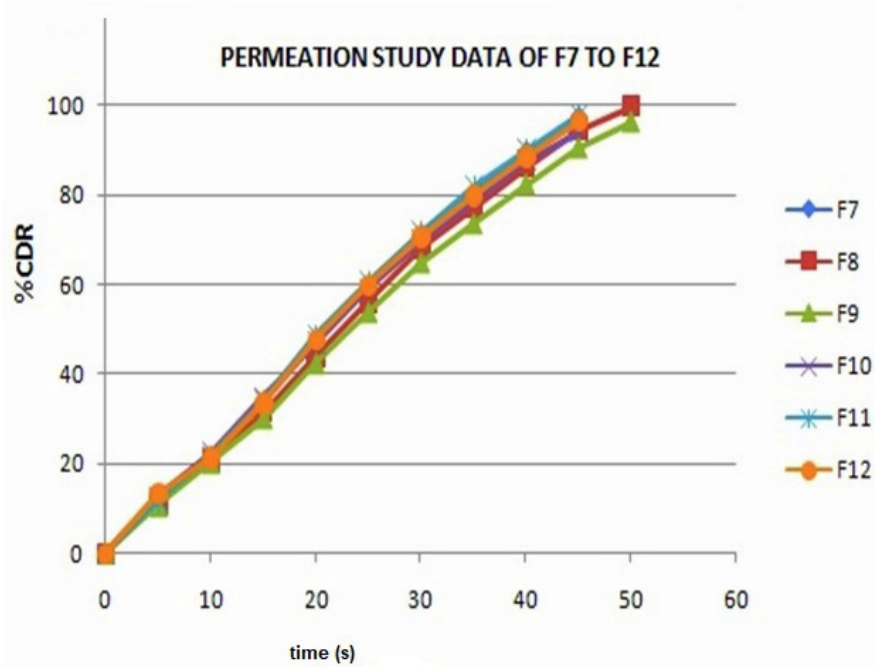

Figure 6: In vitro permeation pattern of F7 to F12 formulations.

solubility of the drug. ${ }^{22}$ All three prepared inclusion complexes showed the uniform distribution of the drug. The dissolution rate of the complexes was found to be increased compared to pure drug probably due to the formation of water-soluble inclusion complexes of the drug with the $\beta$-CD. ${ }^{23,24}$ Among the inclusion complexes prepared, formulation IC2, i.e., the inclusion complex of piroxicam with $\beta$-CD (1:1 ratio) prepared by the kneading method showed a faster dissolution rate (Figure 2). Therefore for the formulation of fast dissolving films polymers such as Sodium CMC and Chitosan and super disintegrants like sodium starch glycolate and crospovidone were selected as an excipient by solvent casting technique. All the formulations were evaluated for their physicochemical parameters. The Thickness of fast dissolving film depends on the concentration of the polymer. Here the concentration of polymer is kept constant. Hence, the thickness of fast dissolving film depends on vary in concentration of the super disintegrating agent. ${ }^{25}$ Low concentration of the super disintegrating agent in F1 $(2 \% \mathrm{w} / \mathrm{v}$ of sodium starch glycolate) may be the reason for the lowest thickness of the film and high concentration of the super disintegrating agent in F9 $(6 \% \mathrm{w} / \mathrm{v}$ of sodium starch glycolate) may be the reason for the highest thickness of the film. ${ }^{26}$ Content uniformity study results confirmed the uniform distribution of the drug in all the formulations. All the films passed the weight variation test as the standard deviation of $\%$ weight variation of individual formulations was found to be within the pharmacopoeial limit, i.e., $\pm 7.5 \%$. Low concentration of the super disintegrating agent in F1 ( $2 \% \mathrm{w} / \mathrm{v}$ of sodium starch glycolate) may be the reason for the lowest weight of the film and high concentration of the super disintegrating agent in F9 (6 \% w/v of sodium starch glycolate) may be the reason for the highest weight of the film. ${ }^{27}$ The surface $\mathrm{pH}$, tensile strength, percentage elongation, folding endurance and \% moisture content of all formulations were found to be within the satisfactory range. Moisture loss is the quantity of moisture transmitted through the unit area of film in unit time indicates films ability to withstand its physicochemical properties under normal conditions. ${ }^{28}$ All the formulated films (F1-F12) were disintegrated rapidly which is a very important property of fast dissolving films. ${ }^{29}$ In vitro, drug release studies confirmed the fast release of the drug from formulations and F6 formulation released the drug faster compared to all other formulations. It was observed that piroxicam easily permeated across the membrane since it belongs to the BCS class II. ${ }^{30}$ So, the result of in vitro permeation study indicates the easy solubilisation and absorption of piroxicam from fast dissolving film. 


\section{CONCLUSION}

The fast dissolving oral films of piroxicam inclusion complexes were developed successfully via solvent casting technique with the intention of obtaining better therapeutic efficiency with patient compliance. Results obtained was found to be encouraging and considered suitable to obtain better action compared to conventional tablets with the convenience of administration. The overall preparation was found to be simple, reproducible and cost-effective. So, it can be concluded that this drug delivery system has the potential of overcoming the drawbacks of currently available conventional tablet formulations.

\section{ACKNOWLEDGEMENT}

The authors acknowledge Srinivas college of Pharmacy, Mangaluru, Karnataka, India for providing the facilities to carry out this work.

\section{CONFLICT OF INTEREST}

The authors declare no conflict of interest.

\section{ABBREVIATIONS}

NSAID: nonsteroidal anti-inflammatory drug; GI fluids: Gastrointestinal fluids; PEG 400: polyethylene glycol 400; ODFs: Oral Disintegrating Films; $\boldsymbol{\beta}$-CD: $\beta$-cyclodextrin; USP: United States Pharmacopeia; Sodium CMC: Sodium Carboxymethyl Cellulose; UV: Ultraviolet; FTIR: Fourier-transform infrared spectroscopy.

\section{REFERENCES}

1. Parkash V, Maan S, Deepika, Yadav S, Hemlata, Jogpal V. Fast disintegrating tablets: Opportunity in drug delivery system. J Adv Pharm Technol Res. $2011 ; 2(4): 223-35$

2. Chaturvedi A, Srivastava P,Yadav S, Bansal M, Garg G, Sharma PK. Fast dissolving films: A review. Curr Drug Deliv. 2011;8(4):373-80.

3. Nagaraju T, Gowthami R, Rajashekar M, Sandeep S, Mallesham M, Sathish D, et al. Comprehensive review on oral disintegrating films. Curr Drug Deliv. 2013;10(1):96-108

4. Bala R, Khanna S, Pawar P, Arora S. Orally dissolving strips: A new approach to oral drug delivery system. Int J Pharm Investig. 2013;3(2):67-76.

5. Joshi P, Patel H, Patel V, Panchal R. Formulation development and evaluation of mouth dissolving film of domperidone. J Pharm Bioallied Sci. 2012;4(Suppl 1):S108-9.

6. Irfan M, Rabel S, Bukhtar Q, Qadir Ml, Jabeen F, Khan A. Orally disintegrating films: A modern expansion in drug delivery system. Saudi Pharm J. 2016;24(5):537-46

7. Sweetman SC. Martindale: The complete drug reference $36^{\text {th }}$ ed. Pharm Press. 2009

8. Park CW, Ma KW, Jang SW, Son M, Kang MJ. Comparison of piroxicam pharmacokinetics and anti-inflammatory effect in rats after intra-articular and intramuscular administration. Biomol Ther. 2014;22(3):260-6.

9. Fabbri A, Cruccu G, Sperti P, Ridolfi M, Ciampani T, Leardi MG, et al. Piroxi- cam-induced analgesia: evidence for a central component which is not opioid mediated. Experientia. 1992;48(11-12):1139-42.

10. Urquhar E. Central analgesic activity of nonsteroidal antiinflammatory drugs in animal and human pain models. Semin Arthritis Rheum. 1993;23(3):198-205

11. Karatas A, Yüksel N, Baykara T. Improved solubility and dissolution rate of piroxicam using gelucire 44/14 and labrasol. Farmaco. 2005;60(9):777-82.

12. Varshosaz J, Khajavinia A, Ghasemlu M, Ataei E, Golshiri K, Khayam I. Enhancement in dissolution rate of piroxicam by two micronization techniques. Dissolution Tech. 2013;20(3):15-23.

13. Nawal A, Rajab, Mohammad S, Jawad. Formulation and in vitro evaluation of piroxicam microsponge as a tablet. Int J Pharm Pharm Sci. 2015;8(2):104-14.

14. Dalmora ME, Oliveira AG. Inclusion complex of piroxicam with beta-cyclodextrin and incorporation in hexadecyltrimethylammonium bromide based microemulsion. Int J Pharm. 1999;184(2):157-64.

15. Ghosh A, Biswas S, Ghosh T. Preparation and evaluation of silymarin $\beta$-cyclodextrin molecular inclusion complexes. J Young Pharm. 2011;3(3):205-10.

16. VaishaliY, Londhe, Umalkar KB. Formulation development and evaluation of fast dissolving film of telmisartan. Ind J Pharm Sci. 2012;74(2):122-6.

17. Prabhu P, Malli R, Koland M, Vijaynarayana K, D'Souza U, Harish N, et al. Formulation and evaluation of fast dissolving films of levocitirizine di hydrochloride. Int J Pharm Investig. 2011;1(2):99-104.

18. Tomar A, Sharma K, Chauhan NS, Mittal A, Bajaj U. Formulation and evaluation of fast dissolving oral film of dicyclomine as potential route of buccal delivery. Int J Drug Dev and Res. 2012;4(2):408-17.

19. Mashru RC, Sutariya VB, Sankalia MG, Parikh PP. Development and evaluation of fast-dissolving film of salbutamol sulphate. Drug Dev Ind Pharm. 2005;31(1):25-34.

20. Lai F, Franceschini I, Corrias F, Sala MC, Cilurzo F, Sinico C, et al. Maltodextrin fast dissolving films for quercetin nanocrystal delivery. A feasibility study. Carbohydr Polym. 2015;121:217-23.

21. Krishna KD, Pradip ST, Navin SR. Preparation and optimization of fast dissolving film of naratr iptan hydrochloride. Recent Pat Drug Deliv Formul. 2017;11(2):124-31.

22. Chaturvedi S, Alim M, Agrawal VK. Solubility and Dissolution enhancement of domperidone using 2-hydroxypropyl- $\beta$ cyclodextrin by kneading method. Asian J Pharm. 2017;11(3):168-75

23. Dua K, Pabreja K, Ramana MV, Lather V. Dissolution behavior of $\beta$-cyclodextrin molecular inclusion complexes of aceclofenac. J Pharm Bioallied Sci. 2011:3(3):417-25.

24. Loh GOK, Tan YTF, Peh KK. Enhancement of norfloxacin solubility via inclusion complexation with $\beta$-cyclodextrin and its derivative hydroxypropyl- $\beta$-cyclodextrin. Asian J Pharm Sci. 2016;11(4):536-46.

25. Galgatte UC, Khanchandani SS, Jadhav YG, Chaudhari PD. Investigation of different polymers, plasticizers and super disintegrating agents alone and in combination for use in the formulation of fast dissolving oral films. Int J Pharm Tech Res. 2013;5(4):146572.

26. Karki S, Kim H, Na SJ, Shin D, Jo K, Lee J. Thin films as an emerging platform for drug delivery. Asian J Pharm Sci. 2016;11(5):559-74.

27. Sharma D. Formulation development and evaluation of fast disintegrating tablets of salbutamol sulphate for respiratory disorders. ISRN Pharm. 2013;2013:674507.

28. Lai KL, Fang Y, Han H, Li Q, Zhang S, Li HY, et al. Orally-dissolving film for sublingual and buccal delivery of ropinirole. Colloids Surf B Biointerfaces. 2018;163:9-18.

29. Pathare YS, Hastak VS, Bajaj AN. Polymers used for fast disintegrating oral films: a review. Int J Pharm Sci Rev Res. 2013:21(1):169-78.

30. Mirza S, Miroshnyk I, Habib MJ, Brausch JF, Hussain MD. Enhanced dissolution and oral bioavailability of piroxicam formulations: Modulating effect of phospholipids. Pharmaceutics. 2010;2(4):339-50.

Article History: Submission Date : 01-09-2018; Revised Date : 07-11-2018; Acceptance Date : 15-11-2018.

Cite this article: Dharmasthala S, Shabaraya AR, Andrade GS, Shriram RG, Hebbar S, Dubey A. Fast Dissolving Oral Film of Piroxicam: Solubility Enhancement by forming an Inclusion Complex with $\beta$-cyclodextrin, Formulation and Evaluation. J Young Pharm. 2019;11(1):01-06. 